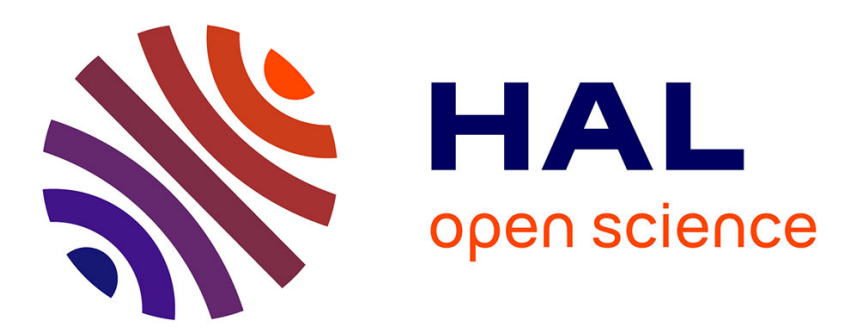

\title{
Determination of polybromodiphenylethers residues in milk cream by gas chromatography-mass spectrometry
}

Said Kinani, Stéphane Bouchonnet, Janine Abjean, Christian Campargue

\section{To cite this version:}

Said Kinani, Stéphane Bouchonnet, Janine Abjean, Christian Campargue. Determination of polybromodiphenylethers residues in milk cream by gas chromatography-mass spectrometry. Food Additives and Contaminants, 2009, 25 (08), pp.1007-1014. 10.1080/02652030701881843 . hal-00577374

\section{HAL Id: hal-00577374 \\ https://hal.science/hal-00577374}

Submitted on 17 Mar 2011

HAL is a multi-disciplinary open access archive for the deposit and dissemination of scientific research documents, whether they are published or not. The documents may come from teaching and research institutions in France or abroad, or from public or private research centers.
L'archive ouverte pluridisciplinaire HAL, est destinée au dépôt et à la diffusion de documents scientifiques de niveau recherche, publiés ou non, émanant des établissements d'enseignement et de recherche français ou étrangers, des laboratoires publics ou privés. 


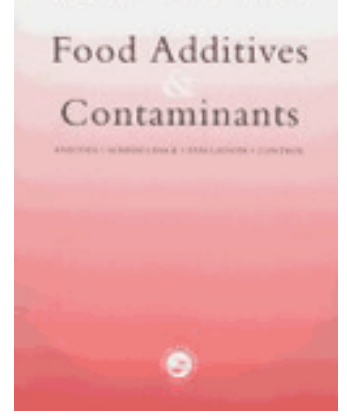

\section{Determination of polybromodiphenylethers residues in milk cream by gas chromatography-mass spectrometry}

\begin{tabular}{|r|l|}
\hline Journal: & Food Additives and Contaminants \\
\hline Manuscript ID: & TFAC-2007-172.R1 \\
\hline Manuscript Type: & Original Research Paper \\
\hline Author: & 17-Dec-2007 \\
\hline Complete List of Authors: & $\begin{array}{l}\text { Kinani, Said; Ecole Polytechnique } \\
\text { Bouchonnet, stéphane; Ecole Polytechnique } \\
\text { Abjean, Janine; Danone } \\
\text { Campargue, Christian; Danone }\end{array}$ \\
\hline Methods/Techniques: & Chromatography - GC/MS, Clean-up, Extraction - ASE \\
\hline Additives/Contaminants: & Environmental contaminants, Trace elements \\
\hline Food Types: & Milk \\
\hline
\end{tabular}

\section{SCHOLARONE ${ }^{\text {m }}$ Manuscripts}




\begin{abstract}
A method to analyse polybromodiphenyl ethers (PBDEs) in milk cream has been optimized. The six PBDEs targeted by the method were chosen on criteria of toxicity and occurrence in environmental matrices. Three methods of extraction were tested and compared in terms of lipid recovery yields and repeatability. The selected sample preparation process includes two steps: extraction by accelerated solvent extraction (ASE) and purification by solid phase extraction (SPE). The preferred method of extraction used a hexane / methylene chloride / methanol (5:2:1, v:v:v) solvent mixture. Three extraction cycles were carried out per sample at a temperature of $80^{\circ} \mathrm{C}$ and a pressure of $1500 \mathrm{psi}$. The method was validated on milk cream samples spiked with the PBDEs of interest. The recoveries for the whole sample preparation process (extraction and cleanup) for cream samples spiked at $10 \mathrm{ng} / \mathrm{g}$ and $100 \mathrm{ng} / \mathrm{g}$ were greater than $80 \%$ (ranging from 81 to $106 \%$ ) at both concentrations for BDE-99, -100, -153 and 154. Recoveries were lower (ranging from 65 to $75 \%$ ) for BDE-28 and BDE-47. PBDEs were quantified by GC/MS detection with selected ion monitoring (SIM) using three ions formed by electron capture. The method was successfully tested on real samples.
\end{abstract}

\title{
Keywords:
}

Polybromodiphenylethers, milk cream, gas chromatography, mass spectrometry, accelerated solvent extraction, solid phase extraction 


\section{Introduction}

Polybromodiphenylethers (PBDEs) are widely used as flame retardants in many industrial products; they are added to polymers which are used in plastics, TV, computers, building materials and textiles to slow down or inhibit fires (Alaee et al. 2003; De Wit 1999). They are of environmental concern because of their high lipophilicity and high resistance to degradation processes; they readily bioaccumulate and have potential endocrine disrupting properties; they can induce genetic recombination, which causes a number of diseases including cancer (Rahman et al. 2001; Helleday et al. 1999). The main findings concerning toxicology of PBDEs are changes in liver weight accompanied by histological alterations in animals (Fernlof et al. 1997). In vitro studies have shown that PBDEs can induct an estrogenic activity (Meerts et al. 2001). Recent studies indicate that the $\mathrm{OH}$ and $\mathrm{H}_{3} \mathrm{CO}$ PBDEs main metabolites of PBDEs can interfer with CYP17, an enzyme which catalyzes an important step in sex steroidogenesis and is responsible for the biosynthesis of dehydroepiandrosterone (Rocío et al. 2006).

During the last few years, PBDEs have been detected in environmental matrices such as soil, sludge (Eljarrat et al. 2004) and sediment (De la Cal et al. 2004; Zegers et al. 2003) as well as in biological matrices: human serum (Covaci et al. 2005), adipose and organ tissue (Saito et al. 2004; Li et al. 2005). Much research interest has recently been focused on the occurrence of PBDEs in mother's milk of countries such as Japan (Akutsu et al. 2003; Eslami et al. 2005), Sweden (Lind et al. 2003), Norway (Thomsen et al. 2002), Turkey (Erdoğrul et al. 2004) and Czech Republic (Kazda et al. 2004). A European Commission Directive has prohibited the use of PBDEs in new electric and electronic components (Commission Directive RoHS 2002/95/EC) since July $1^{\text {st }}$ 2006. The detection of PBDEs is tarditionally performed by GC/MS.

The aim of the present study was to develop a method for PBDEs detection in milk cream, a raw material potentially higher in contamination than the finished product due to the lipophilic property of PBDEs. It was decided to validate the method on cream so that it could be used for the analysis of a variety of dairy products. Special emphasis was given to sample preparation since the development of GC-MS methods (Pirard et al. 2003; Thomsen et al. 


\section{Materials and methods}

\section{Standards and samples}

BDE-28 (2,2',4-tribromodiphenyl ether), BDE-47 (2,2',4,4'-tetrabromodiphenyl ether), BDEs-99 (2,2',4,4',5-pentabromodiphenyl ether) and 100 (2,2',4,4',6-pentabromodiphenyl ether), BDEs-153 (2,2',4,4',5,5'-hexabromodiphenyl ether) and 154 (2,2',4,4',6,6'hexabromodiphenyl ether) and 4,4'-dibromodiphenyl (Purity > 99\%) were purchased from Cambridge Isotope Laboratories (Andover - USA). Hexane, nonane, acetone, methanol, acetonitrile, diethyl ether and methylene chloride were purchased from Sigma-Aldrich (Saint Quentin Fallavier - France); all were at least $99.9 \%$ pure. Anhydrous $\mathrm{Na}_{2} \mathrm{SO}_{4}$ was purchased from Merck (Fontenay Sous Bois, France) and "hydromatrix" (cleaned and sieved diatomaceous earth) from Varian (Les Ulis - France). The samples of milk cream were extracted from milk batches delivered from different regions. The analyzed cream cheese is a commercial product. Toxitubes ${ }^{\circledR} \mathrm{A}$ and $\mathrm{B}$ and $\mathrm{C} 18$ cartridges for solid phase extraction (SPE) were purchased from Varian (Les Ulis, France).

\section{Development of the sample preparation process}

The sample preparation process requires two steps. The first one, referred as "extraction", consists in extracting the lipid content from the cream; the second one, referred as "cleanup", consists in separating PBDEs from the fat.

\section{Extraction}


Three extraction methods were tested and compared in terms of lipid recovery yields: liquidliquid extraction (LLE), accelerated solvent extraction (ASE) and extraction with toxitubes A and $\mathrm{B}$.

Liquid-liquid extraction was carried out in a $100 \mathrm{~mL}$ separatory funnel. To $1 \mathrm{~g}$ of cream were added $10 \mathrm{~mL}$ of methanol and $10 \mathrm{~mL}$ of the extraction solvent: pentane (method 1) and hexane (method 2) were tested. The separatory funnel was manually agitated and the organic phase was transferred into a tube. $3 \mathrm{~mL}$ of a saturated solution of potassium oxalate were added drop to drop to break the emulsion. The methanolic phase was extracted again with 10 $\mathrm{mL}$ of the extraction solvent and the second organic phase was added to the first one.

ASE extractions were carried out using a fully automated ASE 200 system (Dionex, Sunnyvale, CA, USA) fitted with 11- mL ASE cells. Two protocols were tested. Each one used $5 \mathrm{~g}$ of cream thoroughly mixed with $3 \mathrm{~g}$ of Hygromatrix. The first protocol was proposed by Saito et al. to extract lipids from human adipose tissue (Saito et al. 2004). It uses a binary methylene chloride / acetone (1:1, v:v) mixture at a temperature of $100^{\circ} \mathrm{C}$ and a pressure of $1500 \mathrm{psi}$; the ASE cell is purged during $60 \mathrm{~s}$ with $5.5 \mathrm{~mL}$ of solvent. This first protocol involves two extractions per sample. The second protocol was derived from an application note by Dionex to extract PBDE from human breast milk (Dionex application note 2004). It uses a tertiary hexane, methylene chloride, methanol (5:2:1, v:v:v) mixture at a temperature of $80^{\circ} \mathrm{C}$ and a pressure of $1500 \mathrm{psi}$; the ASE cell is purged during $240 \mathrm{~s}$ with $6.0 \mathrm{~mL}$ of solvent. The second extraction protocol includes three extractions per sample.

Extraction with toxitubes was performed according to the following protocol. $4 \mathrm{~mL}$ of water were added to $\mathrm{x} g$ of cream; thre values of $\mathrm{x}$ were tested: $0.10,0.25$ and 0.60 . The mixture was transferred into a toxitube $\mathrm{B}$, automatically mixed by inversion before being centrifuged at $3500 \mathrm{~g}$ during $15 \mathrm{~min}$ at $25^{\circ} \mathrm{C}$.

In all extraction processes, the resulting extract was dried with anhydrous $\mathrm{Na}_{2} \mathrm{SO}_{4}$. The $\mathrm{Na}_{2} \mathrm{SO}_{4}$ residue was rinsed with two aliquots of $2 \mathrm{~mL}$ of the extraction solvent. The organic extract was then taken using a $20 \mathrm{~mL}$ syringe and filtered on two $25 \mathrm{~mm}$ Acrodisc ${ }^{\circledR}$ syringe filters (Pall Life Sciences - Ann Arbor - USA). The mass of extracted fat was determined by gravimetry, according to the following procedure. Before extraction, a collecting vial was dried in an oven at $100^{\circ} \mathrm{C}$ for $30 \mathrm{~min}$, cooled in a desiccator for 1 hour and weighted. After 


\section{Please insert Figure 1 near here}

\section{GC-MS analysis}

All analyses were carried out on a Varian "CP3800" gas chromatograph fitted with a "CP8400" autosampler and connected to a Varian "1200" triple stage quadrupole mass spectrometer. The chromatographic separation was performed on a $60 \mathrm{~m}$ "Factor four VFXMS" capillary column (internal diameter: $0.25 \mathrm{~mm}$, film thickness: $0.25 \mu \mathrm{m}$ ) from Varian. Helium was used as the GC carrier gas and the flow-rate was maintained constant at 1.4 $\mathrm{mL} / \mathrm{min}$ owing to an electronic flow controller. All experiments were performed by automatically injecting the sample in the splitless mode at a rate of $50 \mu \mathrm{L} / \mathrm{sec} .1 \mu \mathrm{L}$ of sample was injected in the experiments concerning the development of the method but a value of 1.5 
$\mu \mathrm{L}$ has been finally retained for the validation procedure according to the detection thresholds required. The injector temperature was $280^{\circ} \mathrm{C}$. The split valve opened after $0.8 \mathrm{~min}$, with a split ratio of $35 / 100$. The capillary column was ramped from an initial temperature of $100^{\circ} \mathrm{C}$, held for $1 \mathrm{~min}$, increased at $20^{\circ} \mathrm{C} / \mathrm{min}$ up to $300^{\circ} \mathrm{C}$ where it was held for $14 \mathrm{~min}$. The total duration of $\mathrm{GC}$ analysis was $25 \mathrm{~min}$. The transfer line was maintained at $300^{\circ} \mathrm{C}$. The ion source and quadrupole temperatures were $150^{\circ} \mathrm{C}$ and $40^{\circ} \mathrm{C}$, respectively. Tuning of the mass spectrometer was automatically performed using the ions resulting from ionization of perfluorotributylamine. Electron capture ionization was performed using methane as thermalization gas at a pressure of $800 \mathrm{~Pa}$. The filament emission current and the electron energy were set to $150 \mu \mathrm{A}$ and $150 \mathrm{eV}$, respectively. The multiplier voltage was automatically set to $1200 \mathrm{~V}$. All experiments were performed in the negative mode, with a scan time of 0.4 sec/spectrum.

\section{Results and discussion GC-MS}

In the electron attachment mode, all PBDEs dissociate to provide only $\mathrm{Br}^{-}$and $\mathrm{HBr}_{2}^{-}$product ions, in agreement with results of previous work. Under electron attachment, 4,4' dibromodiphenyl mainly provides molecular ions $\mathrm{M}^{-}$and $\mathrm{Br}^{-}$ions. A SIM (Selected Ion Monitoring) method has thus been developed. Three ions are monitored for PBDEs ( $\mathrm{m} / \mathrm{z} 78.9$, $\mathrm{m} / \mathrm{z} 80.9$ and $\mathrm{m} / \mathrm{z} 160.8)$ and for the internal standard (m/z 78.9, $\mathrm{m} / \mathrm{z} 80.9$ and $\mathrm{m} / \mathrm{z} 311.9)$. The main disadvantage of this method is its lack of specificity since some brominated compounds may interfere with PBDE peaks in the chromatogram but several studies showed that electron attachment is the ionization mode, which provides by far the lowest detection thresholds for PBDEs. The analytical performance of the GC/MS method for solutions of standards are summarized in Table 1. Limits of quantification (LOQ) were determined for a signal-to-noise ratio of 10 ; they range from $10 \mathrm{pg} / \mathrm{mL}$ for tri and tetra-BDE to $80 \mathrm{pg} / \mathrm{mL}$ for hexa-BDE. Coefficients of variation were determined for ten injections at two concentrations: 2.5 and $30.0 \mathrm{ng} / \mathrm{mL}$ and ranged between 0.5 and $17.7 \%$. For all the PBDEs which were investigated, the coefficient of correlation $\left(r^{2}\right)$ was greater than 0.995 for a concentration range from the LOQ to $50 \mathrm{ng} / \mathrm{mL}$.

Please insert Table 1 near here. 


\section{Please insert Figure 2 near here}

\section{Cleanup}

We estimated the selectivity of the cleanup process by determining the amount of fat eluted through the SPE cartridge as a function of the amount of sample deposited into it. Four amounts were tested: 50, 250, 500 and $1500 \mathrm{mg}$. Fat recovery yields are compared in Figure 3. The uncertainties displayed on it were determined as follows. $\mathrm{M}_{\mathrm{f}} \mathrm{e}$ and $\mathrm{M}_{\mathrm{f}} \mathrm{p}$ being the mass of fat in the sample after extraction and the mass of fat recovered after purification, respectively, the recovery yield of fat $\left(\Gamma_{\mathrm{f}}\right)$ is defined as $\Gamma_{\mathrm{f}}=\left(\mathrm{M}_{\mathrm{f}} \mathrm{p} / \mathrm{M}_{\mathrm{f}} \mathrm{e}\right)$ x 100 and the associated uncertainty is $\ln \left(\Gamma_{\mathrm{f}}\right)=\ln \left(\mathrm{M}_{\mathrm{f}} \mathrm{p}\right)-\ln \left(\mathrm{M}_{\mathrm{f}} \mathrm{e}\right)+\ln (100) . \Delta\left(\Gamma_{\mathrm{f}}\right)=\Gamma_{\mathrm{f}} \mathrm{x}\left[\Delta\left(\mathrm{M}_{\mathrm{f}} \mathrm{p}\right) / \mathrm{M}_{\mathrm{f}} \mathrm{p}+\right.$ $\Delta\left(\mathrm{M}_{\mathrm{f}} \mathrm{e}\right) / \mathrm{M}_{\mathrm{f}} \mathrm{e}$. The uncertainty on the weighting of fat is $0.1 \mathrm{mg}$. Figure 3 shows that fat is well retained on the $\mathrm{C} 18$ phase. Even with a sample amount of $1500 \mathrm{mg}$, the fat was barely eluted (only about $4 \%$ ) and the cartridge was not plugged. The successive use of two cartridges may thus be considered where cleanup of large amounts of sample is required. A loading of $500 \mathrm{mg}$ provided a fat recovery of $0.7 \%$, meaning that $99.3 \%$ of the fat was 
retained on the $\mathrm{C} 18$ phase. This value of $500 \mathrm{mg}$ has been retained for further optimization of the purification step.

\section{Please insert Figure 3 near here}

Figure 4 shows two chromatograms of the same extract of cream spiked at $0.5 \mathrm{ng} / \mathrm{g}$ for each PBDE. The upper chromatogram shows the results from an extract purified on a SPE cartridge containing $2 \mathrm{~g}$ of $\mathrm{C} 18$ phase; it is very noisy and shows evidence of insufficient selectivity of the cleanup using the $2 \mathrm{~g}$ cartridge. The lower chromatogram shows the results from the same extract purified on a SPE cartridge containing $5 \mathrm{~g}$ of $\mathrm{C} 18$ phase; it permits the detection of the six analytes. $5 \mathrm{~g}$-cartridges have thus been retained for further experiments.

\section{Please insert Figure 4 near here}

The recovery from the SPE cleanup step was determined for each PBDE using the GC/MS method described above. A cream extract was divided into six aliquots of $500 \mathrm{mg}$; $30 \mathrm{ng}$ of each PBDE were added to each aliquot. Cleanup was carried out from each spiked sample according to the procedure described in the experimental part. The tube containing the ASE extract was rinsed with $20 \mathrm{~mL}$ of acetonitrile. Mean recovery yields from the cream extract ranged from $43 \%$ for BDE-154 to $79 \%$ for BDE-28 and the associated coefficients of variation for $n=6$ ranged from 6 to $26 \%$. Considering the poor recovery yields and the large values of the corresponding $\mathrm{CV}$, the influence of the rinsing of the tube containing the ASE extract was studied. The SPE process was applied to extract a sample spiked in PBDEs at 50 $\mathrm{ng} / \mathrm{g}$ of fat. The tube was rinsed eight times with $5 \mathrm{~mL}$ of acetonitrile. After each rinsing, the rinsing solution was deposited onto the cartridge and eluted. Each corresponding collected fraction was analyzed by GC/MS. In Figure 5 the recovery yields are plotted as a function of the number of $5 \mathrm{~mL}$-eluted fraction(s) collected. For all PBDEs, the recovery increased with the number of collected fractions to reach a maximum for 5 fractions collected. Under these conditions, recoveries were between 90 and $96 \%$, according to the PBDE considered. The $\mathrm{CV}$ on cleanup recovery yields for five extractions ranged from 1.0 to $5.4 \%$ according to the individual PBDE. This experiment showed the importance of carrying out several rinses and allowed excellent recovery to be achieved with a good CV.

Please insert Figure 5 near here 
The influence of the concentration in PBDE on the recovery was studied as follows. The cleanup was applied to ten samples of $500 \mathrm{mg}$ of extracted cream; five were spiked with $5 \mathrm{ng}$ and five were spiked with $50 \mathrm{ng}$ of each PBDE. Considering each PBDE, the difference in mean recovery yields (comparable to those obtained in the experience described in the previous paragraph) between both concentrations did not exceed $9 \%$ and showed no evidence of a correlation between the recovery yield of the cleanup step and the initial PBDE concentration in the sample.

Figure 6 shows the mean recovery yields for the method overall, i.e. taking into consideration ASE extraction and SPE cleanup. They were determined by spiking ten samples of cream, five at $10 \mathrm{ng} / \mathrm{g}$ and five at $100 \mathrm{ng} / \mathrm{g}$ in each PBDE. Mean recovery yields range from 65 to $101 \%$ for samples at $10 \mathrm{ng} / \mathrm{g}$ and from 69 to $106 \%$ for samples at $100 \mathrm{ng} / \mathrm{g}$. There is no evident concentration effect since recovery yields do not significantly differ comparing both concentrations for a given PBDE. The associated coefficients of correlation range from 1.1 to $5.5 \%$ for the samples spiked at $10 \mathrm{ng} / \mathrm{g}$ and from 3.4 to $9.3 \%$ for the samples spiked at 100 $\mathrm{ng} / \mathrm{g}$, showing the good repeatability of the sample preparation procedure. Gel permeation chromatography (GPC) (Kazda et al. 2004; Dodder et al. 2002; Allae et al 2001) and adsorption chromatography (Päpke et al. 2004; Kazda et al. 2004; De Boer et al. 2000, 2001, 2002) have been widely used for the cleanup of PBDEs extracted from biological compounds. The former technique is not available in our laboratories. Nowadays, "classical" adsorption chromatography with silica and/or alumina columns tends to be replaced by SPE which reduces solvent consumption and allows total automation.

\section{Please insert Figure 6 near here}

\section{Method validation}

In preliminary tests, traces of PBDEs (especially BDE-47) were systematically detected in creams from different regions and contamination by plastic tubes has been suspected. The whole sample preparation method has been carried out two times on two cream samples. In the first extraction, Eppendorf plastic tubes were used to store samples; in the second one, plastic tubes were replaced by glass tubes. The comparison of results obtained by GC-MS analysis clearly showed a PBDE contamination of the sample by the plastic tubes. Even 
though the amounts of PBDEs detected were very low (below the quantitation threshold of the method), plastic tubes were discarded of the sample extraction procedure in further work.

Cream samples were spiked at six concentrations ranging from 0.1 to $10 \mathrm{ng} / \mathrm{g}$ of fat for BDEs28, $-47,-99$ and -100 , and from 0.2 to $20.0 \mathrm{ng} / \mathrm{g}$ of fat for BDEs-153 and -154 for which preliminary tests showed higher detection limits. To estimate possible matrix effects, standard solutions of PBDEs were prepared at the same concentrations. In each case the internal standard (dibromobiphenyl) was added at $0.10 \mathrm{ng} / \mathrm{g}$. The chromatographic response was proportional to the PBDE concentration in cream on all the studied concentration range with $r^{2}>0,995$ for each congener. The comparison of calibration lines with and without matrix interferents shows a matrix effect so slight that it can be neglected. Accuracy and repeatability were estimated on four consecutive dosages at two concentrations in PBDEs: 0.6 and $6.0 \mathrm{ng} / \mathrm{g}$ of fat for BDEs-28, -47, -99 and $-100,1.2$ and 12.0 ng/g for BDEs-153 and -154. In terms of repeatability, the method provides satisfying CV ranging from 6.3 to $14.5 \%$ at the lowest concentration and from 3.5 to $4.6 \%$ at the highest one. In terms of accuracy, the determined amounts are systematically lower than expected: between 78 and $93 \%$ of the expected amount at the lowest concentration and between 78 and $87 \%$ of the expected amount at the highest one. The method systematically under evaluates the PBDE concentration in cream by about 10 to $20 \%$. Given the good recovery ratios (>90\%) of the cleanup process, this underevaluation suggests that all PBDEs are not in the fat and that some of them remain in the aqueous phase during the extraction step.

\section{Application to real samples}

\section{Milk cream}

Figure 7 shows the chromatograms obtained from batches of cream from four different suppliers. In all cases, traces amounts of BDE-47 were detected below the limit of quantition of the method. The mean value of BDE-47 in these cream extracts could very empirically estimated at $0.02 \mathrm{ng} / \mathrm{g}$ of fat. Other PBDEs among the six congeners were not detected.

\section{Please insert Figure 7 near here}

\section{Cream cheese}

The applicability of the method was also tested on cream cheese. Four samples of $22 \mathrm{~g}$ of cream cheese underwent ASE extraction with poor recovery yields of fat ranging from 45 to $47 \%$. After SPE cleanup, the four extracts were analyzed by GC-MS. Quantification was not possible because of the difficulty to get good fat recovery from cream cheese, but there were 
nevertheless indications of the presence of BDEs-47, -99 and -100 at low levels when samples were analysed.

\section{Conclusion}

A method has been developed for routine analysis of six polybromodiphenyl ethers (PBDE) in milk cream. Special attention has been focused on PBDEs extraction from cream. Sample preparation involves two steps. The first one consists in extracting fat from cream by ASE. The second step, referred as "cleanup", uses SPE to separate PBDEs from fat. Recovery yields of the whole sample preparation process were estimated between 65 and $101 \%$ at 10ng/g, with $\mathrm{CV}$ ranging from $3.5 \%$ to $14.5 \%$ for $\mathrm{n}=6$, according to the PBDE considered. PBDEs were analyzed by GC-NCI-MS. The GC-MS method suffers a lack of selectivity because the PBDEs which were analyzed provided only $\mathrm{Br}-$ and $\mathrm{HBr}_{2}$ - ions under electron attachment conditions, in agreement with previous work; nevertheless, it is very sensitive and permited to reach detection thresholds of $0.1 \mathrm{ng} / \mathrm{g}$ of fat for tri-, tetra- and penta-BDEs and $0.2 \mathrm{ng} / \mathrm{g}$ of fat for hexa-BDEs. In terms of accuracy, the method systematically under estimates the PBDE concentration in cream by about 10 to $20 \%$, suggesting that some PBDEs remain in the aqueous phase during the extraction step. Evidence has been found of sample contamination by the PBDEs contained in plastic parts of the apparatus, which must be removed from the sample preparation equipment and replaced by glass parts. The analysis of real samples of cream and cream cheese showed the reliability of the method. Some traces of BDE- 47 were detected in different milk cream batches. BDEs-47, -99 and -100 were found in cream cheese samples. In all cases, PBDEs were not detected at concentrations above the limit of quantification of the method $(0.1 \mathrm{ng} / \mathrm{g})$. 


\section{References}

Akutsu K, Kitagawa M, Nakazawa H, Makino T, Iwazaki K, Oda H, Hori S. 2003. Timetrend (1973-2000) of polybrominated diphenyl ethers in Japanese mother's milk. Chemosphere. 53:645-654.

Alaee M, Arias P, Sjödin A, Bergman A. 2003. An overview of commercially used brominated flame retardants, their applications, their use patterns in different countries/regions and possible modes of release. Environment International 29:683-689.

Alaee M., Sergeant DB, Ikonomou MG, Urossl JM. 2001. A gas chromatography/high resolution mass spectrometry (GC-HRMS) method of determination of polybrominated diphenyl ethers in fish. Chemosphere 44:489-1495.

Björklund J, Tollbäck P, Hiärne C, Dyremark E, Östman C. 2004. Influence of the injection technique and the column system on gas chromatographic determination of polybrominated diphenyl ethers. J. Chromatogr. A. 1041:201-210.

Bordet F, Inthavong D. 2003. Dosage des pesticides organochlorés, pyrethrinoïdes et PCB (Polychlorobiphényles) dans les aliments gras - Note de service DGAL/SDSSA/SDRRCC/ N2003-8141 du Ministère de l'agriculture, de l'alimentation, de la pêche et des affaires rurales.

Cantón RF, Sanderson JT, Nijmeijer S, Bergman Å, Letcher RJ, Van den Berg M. 2006. In vitro effects of brominated flame retardants and metabolites on CYP17 catalytic activity: A novel mechanism of action? Toxicology and Applied Pharmacology 216:274-281.

Covaci A, Voorspoels S. 2005. Optimization of the determination of polybrominated diphenyl ethers in human serum using solid-phase extraction and gas chromatography-electron capture negative ionization mass spectrometry. J. Chromatogr. B. 827:216-223.

Darnerud PO, Eriksen GS, Jóhannesson T, Larsen PB, Viluksela M. 2001. Polybrominated diphenyl ethers: occurrence, dietary exposure and toxicology. Environ. Health Perspect. 109 (suppl 1):49-68. 
De Boer J, Allchin C, Law R, Zegers B, Boon JP. 2001. Method for the analysis of polybrominated diphenyl ethers in sediment and biota. Trends Anal. Chem. 20:591-599.

De Boer J, Cofino WP. 2002. First word-wide interlaboratory study on polybrominated diphenyl ethers (PBDEs). Chemosphere 46:625-633.

De Boer J, De Boer K, Boon JP. 2000. Polybrominated biphenyls and diphenyls ethers. New types of persistent halogenated compounds. In: the Handbook of Environmental Chemistry. Vol. 3, Part K. Paasivirta, J. (Ed). Springer-verlag, New York, NY, pp. 61-96.

De la Cal A, Eljarrat E, Barecelo D. 2003. Determination of 39 polybrominated diphenyl ether congeners in sendiment samples using fast selective pressurized liquid extraction and purification. J. Chromatogr. A. 1021:165-173.

De Wit CA. 1999. An overview of brominated flame retardants in the environment. Chemosphere 46:583-624.

De Wit CA. 1999. Brominated flame retardants in the environment - an overview. Organohalogen Compounds 40:329-332.

Dodder N, Strandberg B, Hites RA. 2002. Concentrations and spatial variations of polybrominated diphenylethers in fish and air from the North-Eastern United States. Environ. Sci. Technol. 36:146-151.

Eljarrat E, Barecelo D. 2004. Sample handling and analysis of brominated flame retardants in soil and sludge samples. Trends in Analytical chemistry 23:727-736.

Erdoğrul Ö, Covaci A, Kurtul N, Schepens P. 2004. Levels of organohalogenated persitent pollutants in human milk from Kahramanmaraş region, Turkey. Environ. Int. 30:659-666. 
Eslami B, Koizumi A, Ohta S, Inoue K, Aozasa O, Harada K, Yoshinaga T, Date C, Fujii S, Fujimine Y, Hachiya N, Hirosawa I, Koda S, Kusaka Y, Murata K, Nakatsuka H, Omae K, Saito N, Shimbo S, Takenaka K, Takeshita T, Todoriki H, Wada Y, Watanabe T, Ikeda M. 2006. Large-scale evaluation of the current level of polybrominated diphenyl ethers (PBDEs) in breast milk from 13 regions of Japan. Chemosphere 63:554-561.

Fernlof G, Gadhasson I, Podra K, Darnerud PO, Thuvander A. 1997. Lack of effects of some individual polybrominated diphenyl ethers and polychlorinated biphenyl congeners on human lymphocite functions in vitro. Toxicol. Lett. 90(2-3): 189-197.

Fontanals N, Barri T, Bergström S, Jönsson JÅ. 2006. Determination of polybrominated diphenyl ethers at trace levels in environmental waters using hollow-fiber microporous membrane liquid-liquid extraction and gas chromatography-mass spectrometry. J. Chrom. A, 1133: 41-48.

Helleday T, Tuominrn KL, Bergman A, Jensson D. 1999. Brominated flame retardants induce intragenic recombination in mammalian cells. Mut. Res. 439(2): 137-147.

Ilonka A, Meerts TM, Letcher RJ, Hoving S, Marsh G, Bergman ^, Lemmen JG, Van der Burg B, Brouwer A. 2006. In Vitro Estrogenicity of Polybrominated Diphenyl Ethers, Hydroxylated PBDEs, and Polybrominated Bisphenol A Compounds.Environmental Health Perspectives 109:399-407.

Kazda R, Hajšlová J, Poutska J, Čajka T. 2004. Determination of polybrominated diphenyl ethers in human milk samples in the Czech Republic. Comparative study of negative chemical ionization mass spectrometry and time-of-flight high-resolution mass spectrometry. Analytica Chimica Acta. 520:237-243.

Li QQ, Loganath A, Chong YS, Obbard JP. 2005. Determination and occurrence of polybrominated diphenyl ethers in maternal adipose tissue from inhabitants of Singapore. J. Chromatogr. B. 819:253-257. 
Lind Y, Darnerud PO, Atuma S, Aune M, Becker W, Bjerselius R, Cnattingius S, Glynn A. 2003. Polybrominated diphenyl ethers in breast milk from Uppsala County, Sweden. Environ. Research 93:186-194.

Päpke O, Fürst P, Herrmann T. 2004. Determination of polybrominated diphenylethers (PBDEs) in biological tissues with special emphasis on QC/QA measures. Talenta. 63:12031211.

Pirard C, De Pauw E, Focant JF. 2003. New strategy for comprehensive analysis of polybrominated diphenyl ethers, polychlorinated dibenzo-p-dioxins, polychlorinated dibenzofurans and polychlorinated biphenyls by gas chromatography coupled with mass spectrometry. J. Chromatogr. A. 998:169-181.

Rapid determination of polybrominated diphenyl ethers (PBDEs) in biosolids and waste samples using accelerated solvent extraction (ASE®) http://www1.dionex.com/enus/webdocs/38496_AN351_V22.pdf

Rahman F, Langford KH, Scrimshaw MD, Lester JN. Polybrominated diphenyl ether (PBDE) flame retardants. The Science of the Total Environment 275:1-17.

Saito K, Sjödin A, Sandau CD, Davis MD, Nakazawa H, Matsuki Y, Patterson Jr DJ. 2004. Develoment of a accelerated solvent extraction and gel permeation chromatography analytical method for measuring persistent organohalogen compounds in adipose and organ tissue analysis. Chemosphere 57:373-381.

She J, Holden A, Sharp M, Tanner M, Williams-Derry C, Hooper K. 2007. Polybrominated diphenyl ethers (PBDEs)and polychlorinated biphenyls (PCBs) in breast milk from the Pacific Northwest. Chemosphere 67:S307 -S317.

Thomsen C, Haug LS, Leknes H, Lundanes E, Becher G, Lindström G. 2002. Comparing electron ionization high resolution and electron capture low-resolution mass spectrometric determination of polybrominated diphenyl ethers in plasma, serum and milk. Chemosphere 46:641-648. 
Tollbäck P, Björklund J, Östman C. 2003. Large-volume programmed-temperature vaporiser injection for fast gas chromatography with electron capture and mass spectrometric detection of polybrominated diphenyl ethers. J. Chromatogr. A. 991:241-253.

Xu HY, Zou JW, Yu QS, Wang YH, Zhang JY, Jin HX. 2007. QSPR/QSAR models for prediction of the physicochemical properties and biological activity of polybrominated diphenyl ethers. Chemosphere 66:1998 -2010.

Zegers BN, Lewis WE, Booij K, Smittenberg RH, Boer W, De Boer J, Boon JP. 2003. Levels of polybrominated diphenyl ether flame retardants in sediment cores from western Europe. Environ. Sci. Technol. 37:3803-3807. 


\section{Captions for figures}

Figure 1. Experimental protocol used to compare the methods of extraction and to optimize the C18-SPE purification step

Figure 2. Mean recovery yields of fat from cream and corresponding CV $(n=10)$ for each protocol of extraction tested. Numbers on the abscissa axis refer to the method used; the corresponding methods are described the text.

Figure 3. Recovery yields of fat and coefficients of variation associated to the SPE purification step as a function of the amount on fat deposited onto the $2 \mathrm{~g}-\mathrm{C} 18$ cartridge

Figure 4. Comparison of chromatograms recorded from extracts of cream. The upper chromatogram results from an extract purified on a SPE cartridge containing $2 \mathrm{~g}$ of C18 phase. The lower chromatogram results from the same extract purified on a SPE cartridge containing $5 \mathrm{~g}$ of $\mathrm{C} 18$ phase.

Figure 5. Cumulated recovery yields, for each PBDE, as a function of the number of $5 \mathrm{~mL}-$ eluted fractions collected

Figure 6. Mean recovery yields for the complete sample preparation process determined at two concentrations of PBDEs in cream: $10 \mathrm{ng} / \mathrm{g}$ and $100 \mathrm{ng} / \mathrm{g}$

Figure 7. GC-NCI-MS chromatogram of a milk cream extract 


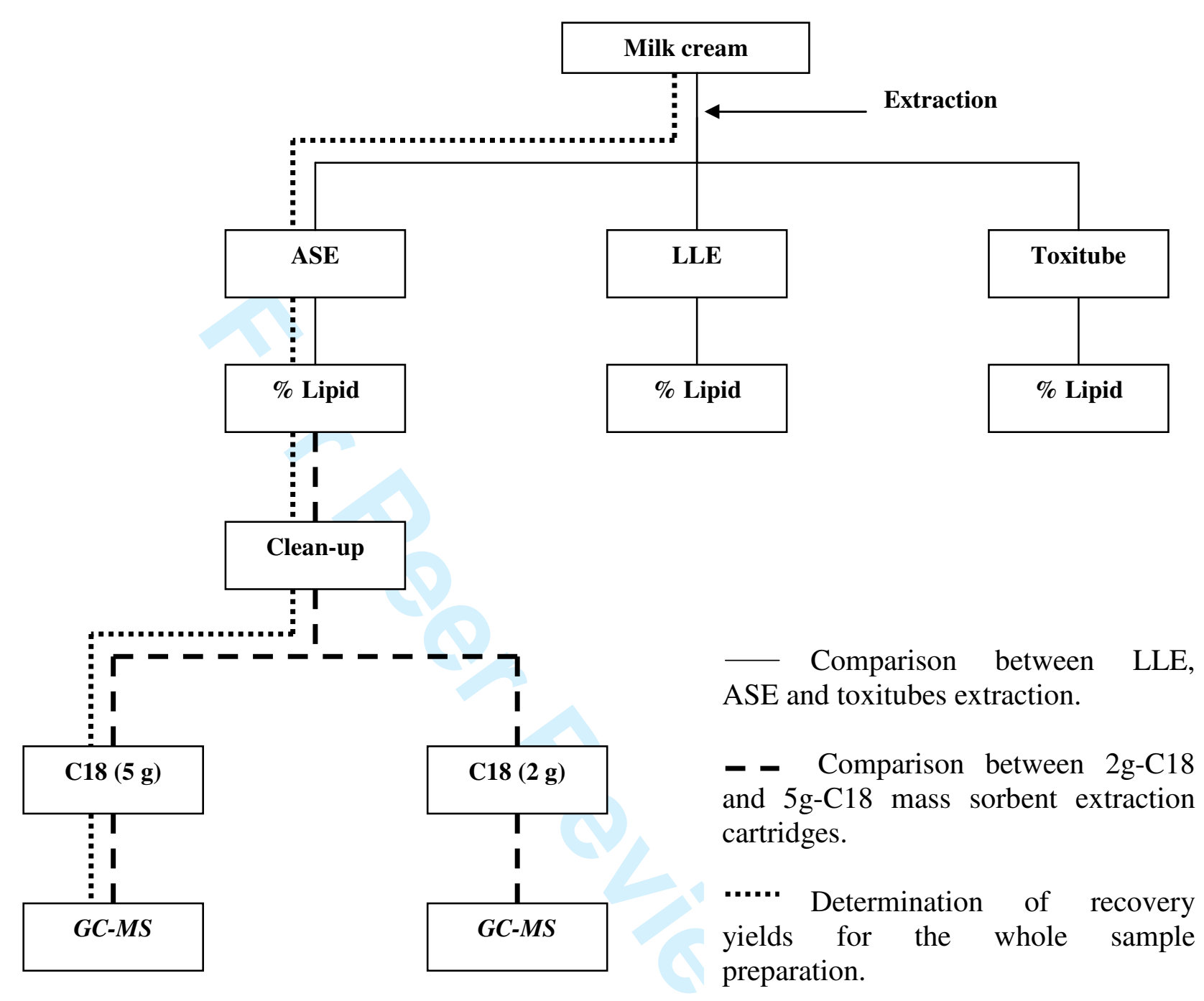

Figure 1. Experimental protocol used to compare the methods of extraction and to optimize the C18-SPE purification step 


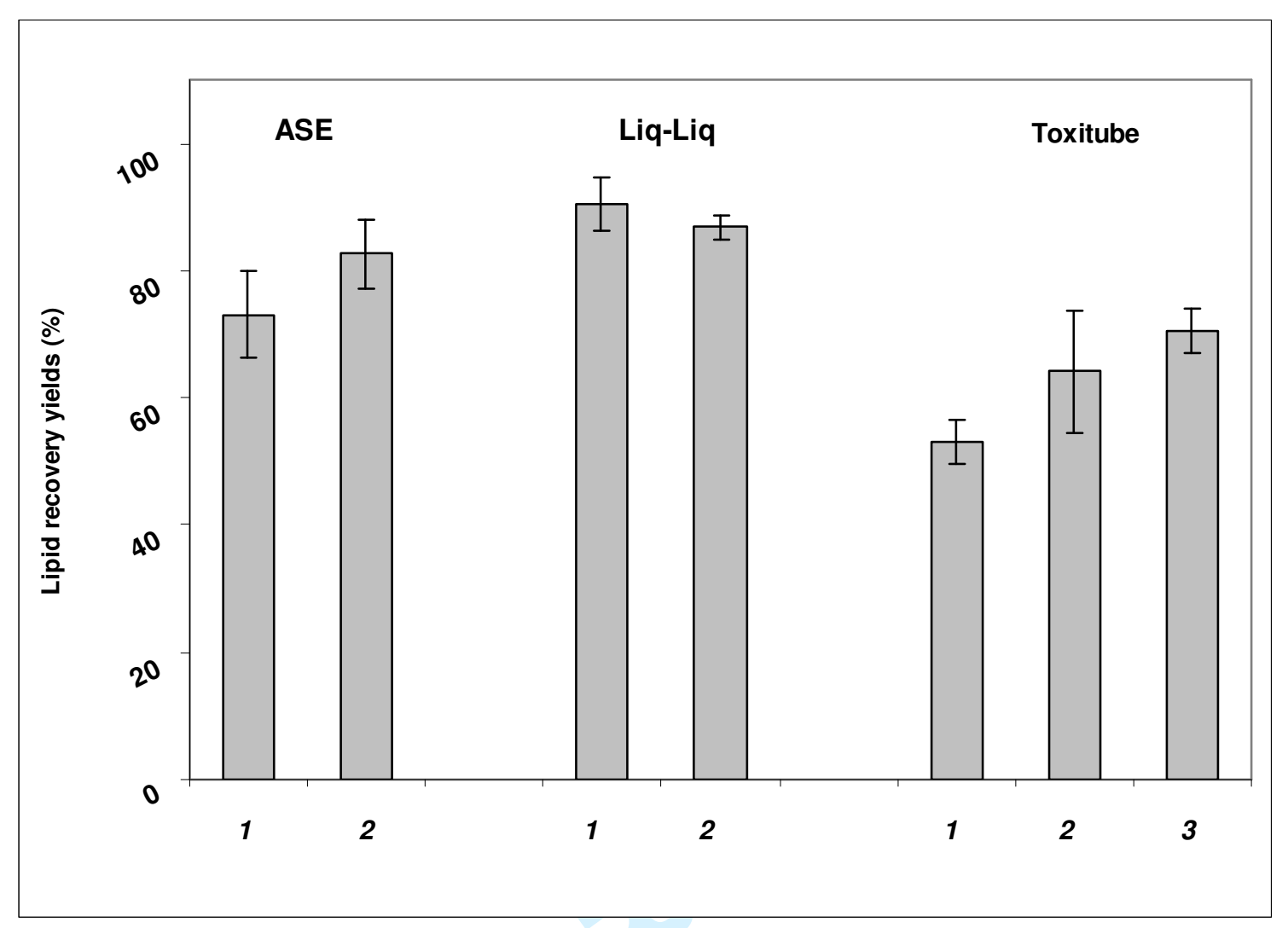

Figure 2. Mean recovery yields of fat from cream and corresponding CV $(n=10)$ for each protocol of extraction tested. Numbers on the abscissa axis refer to the method used; the corresponding methods are described the text. 


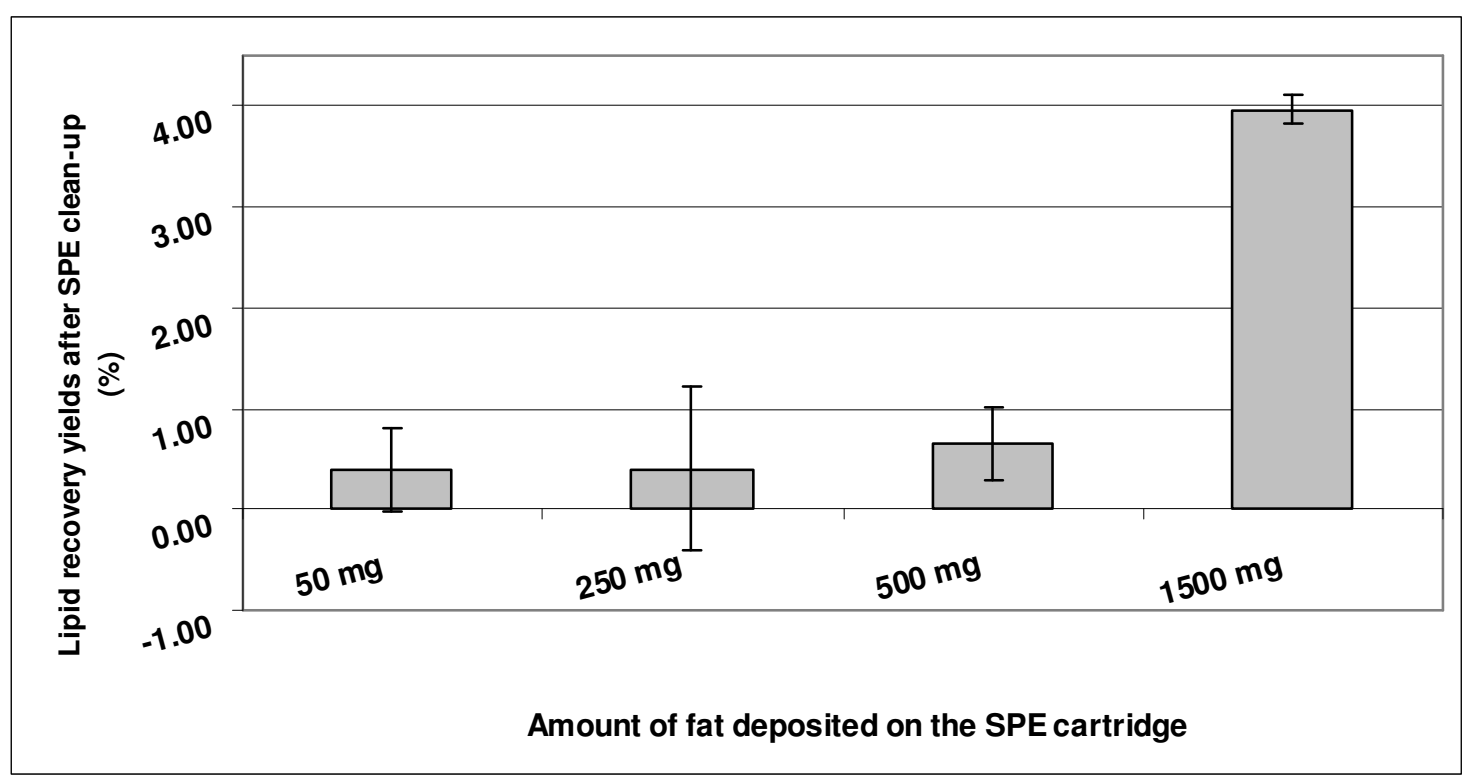

Figure 3. Recovery yields of fat and coefficients of variation associated to the SPE purification step as a function of the amount on fat deposited onto the $2 \mathrm{~g}$-C18 cartridge 


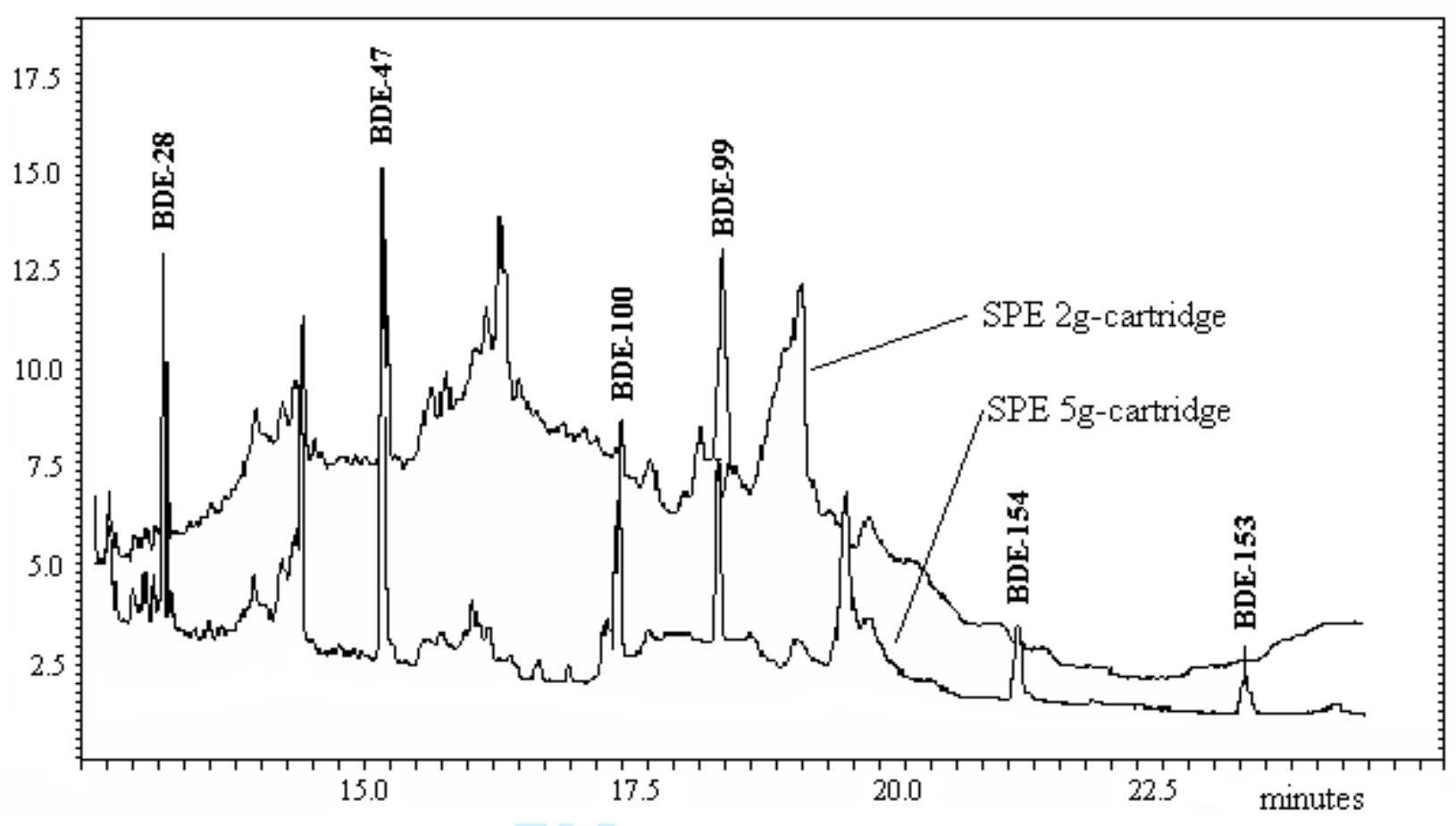

Figure 4. Comparison of chromatograms recorded from extracts of cream. The upper chromatogram results from an extract purified on a SPE cartridge containing $2 \mathrm{~g}$ of C18 phase. The lower chromatogram results from the same extract purified on a SPE cartridge containing $5 \mathrm{~g}$ of $\mathrm{C} 18$ phase. 


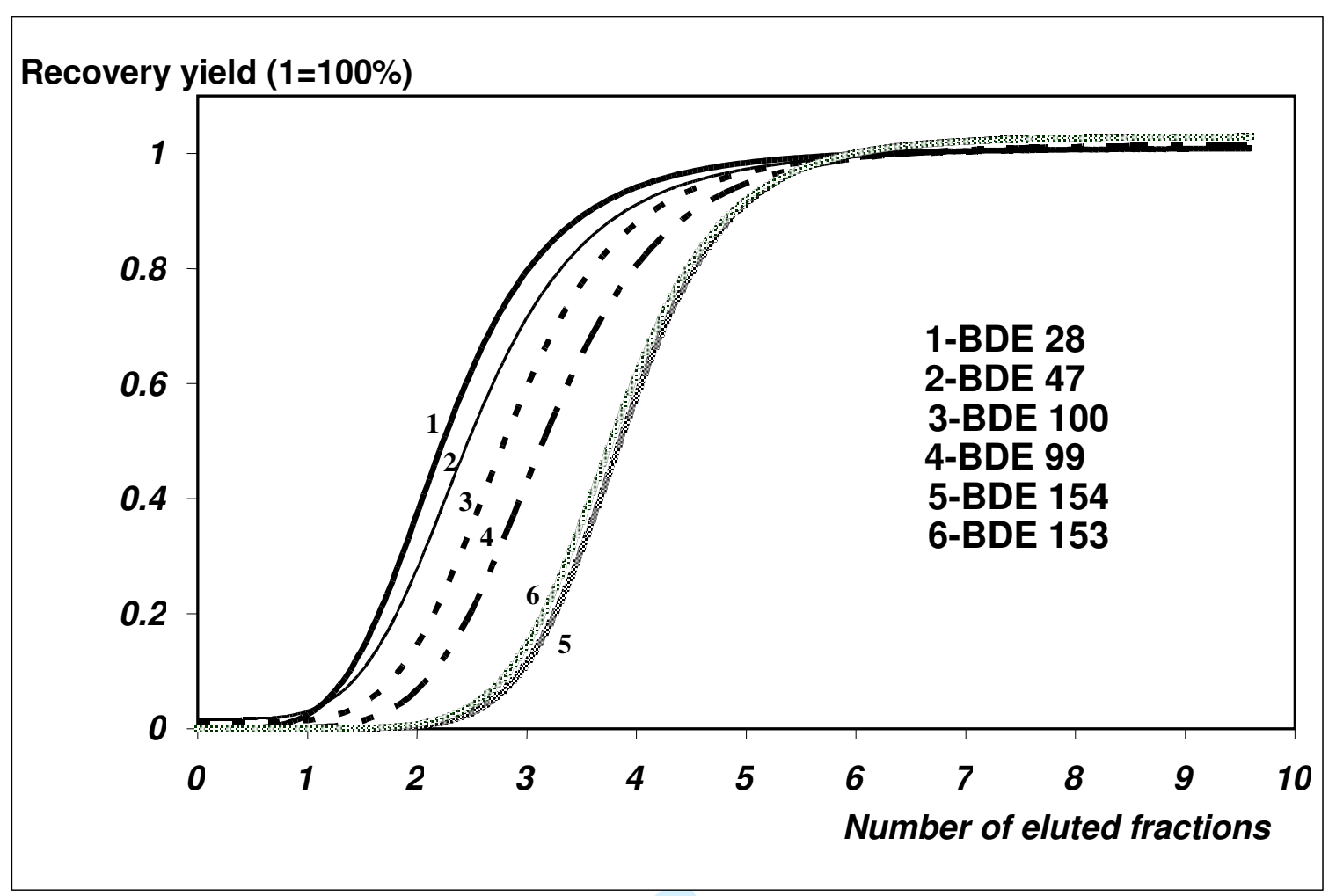

Figure 5. Cumulated recovery yields, for each PBDE, as a function of the number of $5 \mathrm{~mL}-$ eluted fractions collected 


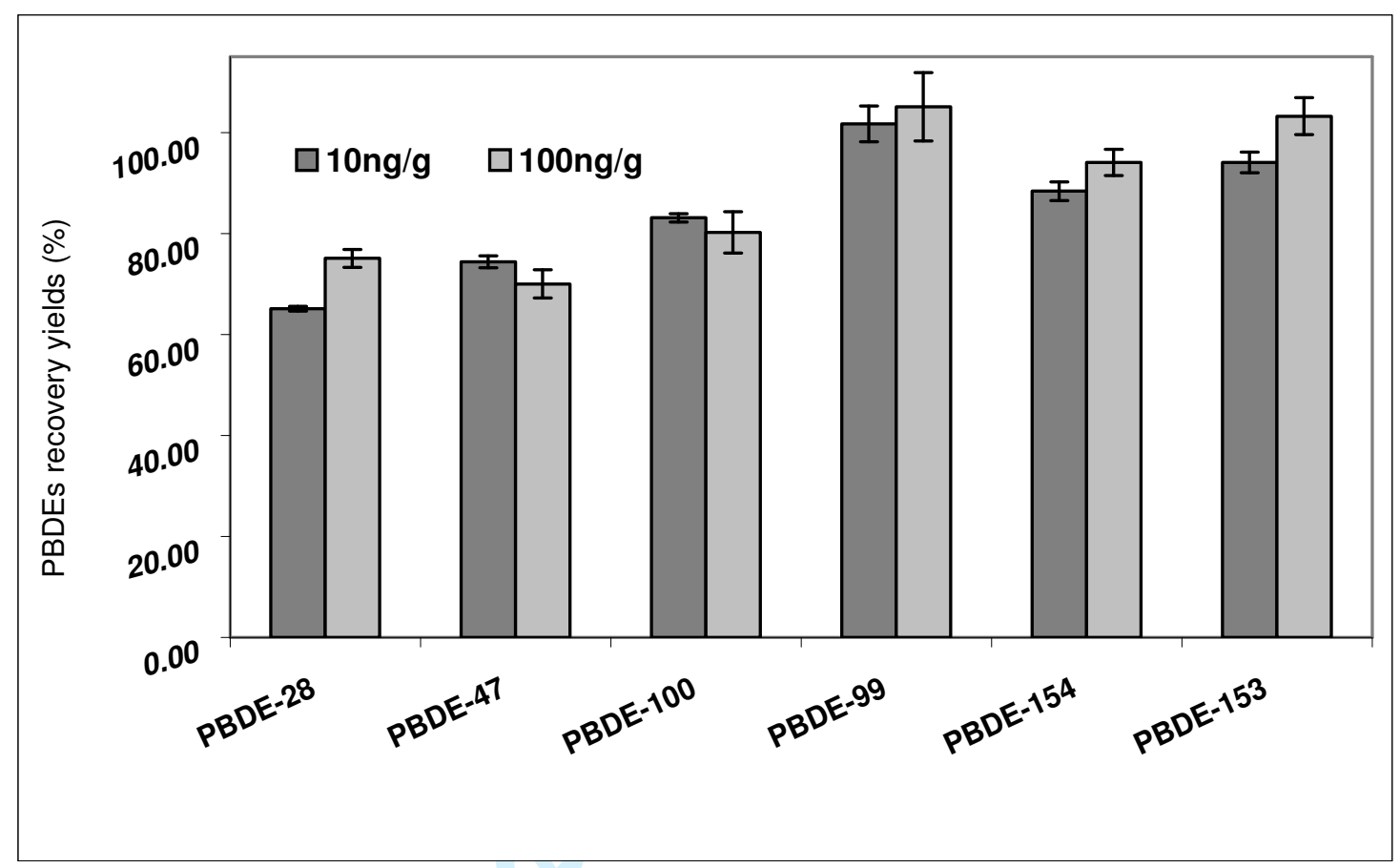

Figure 6. Mean recovery yields for the complete sample preparation process determined at two concentrations of PBDEs in cream: $10 \mathrm{ng} / \mathrm{g}$ and $100 \mathrm{ng} / \mathrm{g}$ 


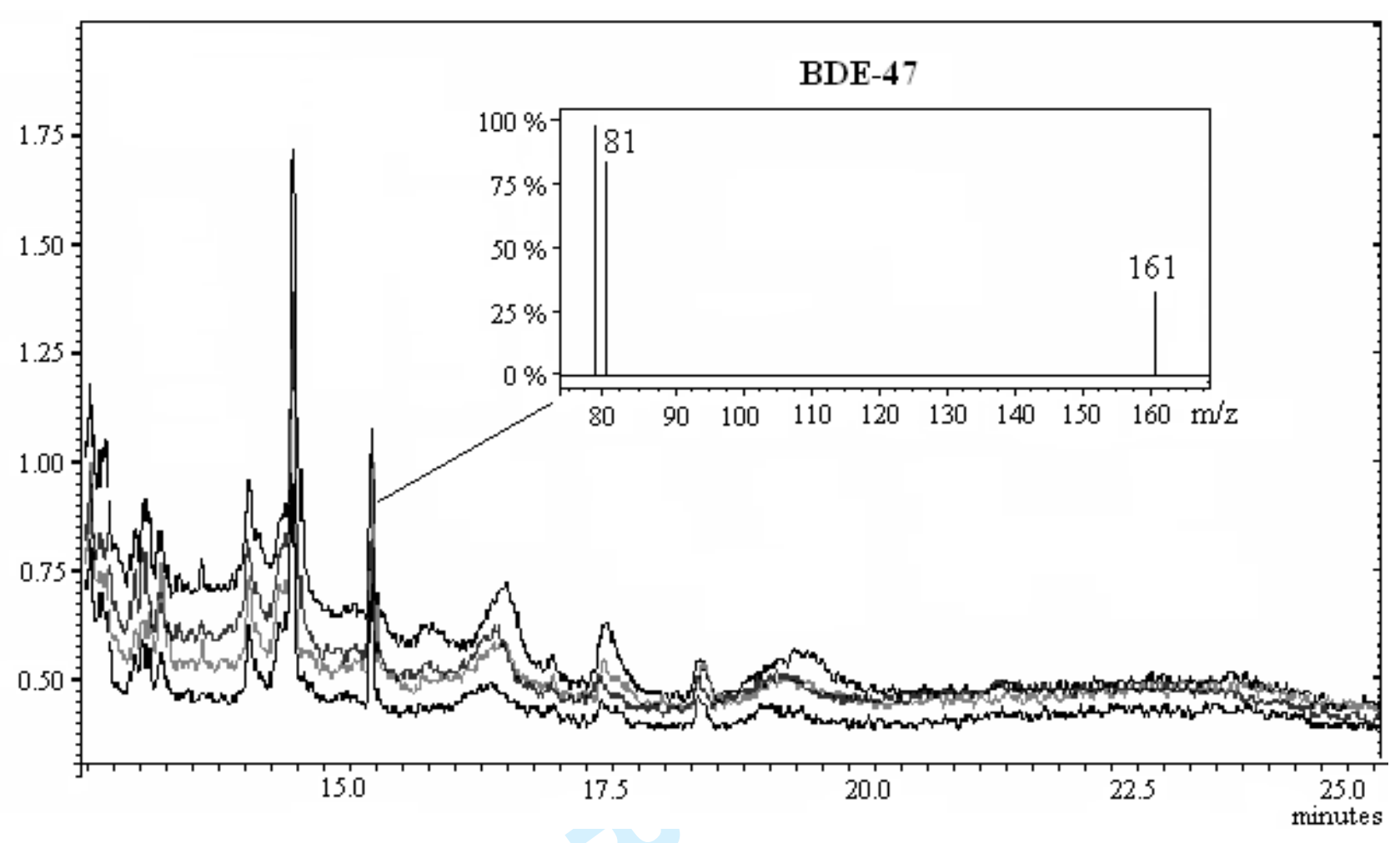

Figure 7. GC-NCI-MS chromatogram of a milk cream extract 


\begin{tabular}{|c|c|c|c|c|c|c|}
\hline \multirow{2}{*}{ Analyte } & $\begin{array}{c}\mathrm{LOD}^{\mathrm{a}} \\
(\mathrm{pg} / \mathrm{mL})\end{array}$ & $\begin{array}{c}\mathrm{LOQ}^{\mathrm{b}} \\
(\mathrm{pg} / \mathrm{mL})\end{array}$ & Linearity range & $\mathrm{r}^{2}$ & \multicolumn{2}{|c|}{$\mathrm{CV}(\%)$} \\
\cline { 5 - 7 } BDE-28 & 3 & 10 & $\begin{array}{l}10 \mathrm{pg} / \mathrm{mL} \\
50 \mathrm{ng} / \mathrm{mL}\end{array}$ & 0.999 & 4.5 & 0.5 \\
\hline BDE-47 & 3 & 10 & $\begin{array}{l}10 \mathrm{pg} / \mathrm{mL} \\
50 \mathrm{ng} / \mathrm{mL}\end{array}$ & 0.998 & 6.2 & 0.7 \\
\hline BDE-99 & 8 & 20 & $\begin{array}{l}20 \mathrm{pg} / \mathrm{mL} \\
50 \mathrm{ng} / \mathrm{mL}\end{array}$ & 0.998 & 5.8 & 1.1 \\
\hline BDE-100 & 8 & 20 & $\begin{array}{l}20 \mathrm{pg} / \mathrm{mL} \\
50 \mathrm{ng} / \mathrm{mL}\end{array}$ & 0.997 & 5.2 & 2.2 \\
\hline BDE-153 & 25 & 80 & $\begin{array}{l}80 \mathrm{pg} / \mathrm{mL} \\
50 \mathrm{ng} / \mathrm{mL}\end{array}$ & 0.997 & 17.7 & 3.6 \\
\hline BDE-154 & 25 & 80 & $\begin{array}{l}80 \mathrm{pg} / \mathrm{mL} \\
50 \mathrm{ng} / \mathrm{mL}\end{array}$ & 0.998 & 10.1 & 3.3 \\
\hline
\end{tabular}

Table 1. Main characteristics of the GC-NCI- MS method on standard solutions

${ }^{\mathrm{a}}$ Limit of detection

${ }^{\mathrm{b}}$ Limit of quantitation 